ered seem promising and will hopefully lead to a better description and modelling of the hydrological characteristics of the Keuper soils under natural forest. Relations between abiotic and biotic factors are also of large interest and form an interesting object for further research. On a longer term, the effects of forest management can be studied as the forest will be partially cleared by cutting some of the beeches and hornbeams to improve the conditions for other trees. Heavy machinery used in the forest to extract trees might be expected to destroy many of the macropore systems and to alter the hydraulic properties of the soil, making the drainage of the forest even more difficult than it already is.

\section{References}

BONELL, M., HENDRIKS, M.R.., IMESON, AC. \& HAZELHOFF, L. (1984): The generation of storm runoff in forested clayey drainagebasin in Luxemburg. Journal of Hydrology 71, 53-77.

BOUMA, J., DEKKER, L.W. \& HUILWIJK, C.J. (1981): A field method for measuring short circuiting in clay soils. Journal of Hydrology 52, 347-354.

BROEK, T.v.d. (1988): Pedogenesis on forested slopes of the Keupermarls: clay dispersion and the formation of an abrupt texture change. In: Exc. Guide 4th Benelux Coll IV 25-30.

CAMMERAAT, L.H. \& IMESON, A.C. (1988): The discontinuity of geomorphological processes in uniform forested drainage basin. CATENA, in press.

DUYSINGS, J.J.H.M. (1985): Streambank contribution to the sediment budget of a forest stream. Dissertation.

DUYSINGS, J.J.H.M. (1987): A sediment budget for a forested catchment in Luxembourg and its implications for channel development. Earth Surf. Proc. and Landf. 6, 235-250.

HOOFF, P.P.M. v. (1983): Earthworm activity as a cause of splash erosion in a Luxembourg forest. Geoderma 31, 195-204.
IMESON, A.C. \& VIS, M. (1984): The output of sediments and solutes from forested and cultivated clayey drainage basins in Luxembourg. Earth Surf. Proc. and Landf. 9, 585-594.

IMESON, A.C., VIS, M. \& DUYSINGS, J.J.H.M. (1984): Surface and subsurface sources of suspended solids in forested drainage basins in the Keuper region of Luxembourg. In : Catchment Experiments in Fluvial Geomorphologie. T.P. Burt \& D.E. Walling (Eds.), GeoBooks, Norwich.

IMESON, A.C. (1986): Investigation of volumetric changes in clayey soils related to subsurface water movement and piping. Z. Geomorph. N.F. Suppl. Band 60, 115-130.

IMESON, A.C. \& JUNGERIUS, P.D. (1977): The widening of valley incisions by soilfall in a forested area, Luxembourg. Earth Surf. Proc. and Landf. 2, 141-152.

STIPHOUT, T. v., LANEN, H. v., BOERSMA, O. \& BOUMA, J. (1987): The effect of bypass flow and internal catchment of rain on the water regime in a caly loam grassland soil. Journal of Hydrology 95, 1-11.

VERSTRATEN, J.M. \& DOPHEIDE, J. (1984): On the contribution of athmospheric deposition to weathering in a forsted ecosystem, Luxemburg. Internal report Univ. of Amsterdam.

Address of authors:

L.H. Cammeraat and A.C. Imeson

Laboratory of Physical Geography and Soil Science Dapperstraat 115

1093 BS Amsterdam

The Netherlands 


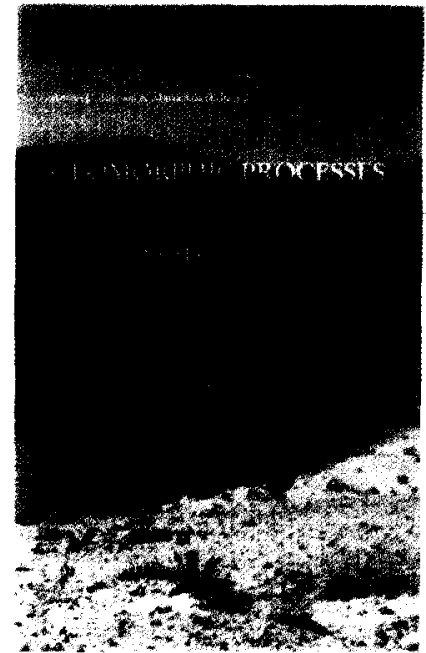

Preface
Anton C. Imeson \& Maria Sala:

\section{GEOMORPHIC PROCESSES}

\author{
In Environments With Strong \\ Seasonal Contrasts \\ Vol. 1: HILLSLOPE PROCESSES \\ CATENA SUPPLEMENT 12, 1988 \\ Price: DM $149,-/$ US $\$ 88$. -
}

ISSN 0722-0723/ISBN 3-923881-12-3

Export of Dissolved Elements in an Evergreen-Oak Forested Watershed in the Montseny Mountains (NE Spain)

M. Sala

Slope Runoff and Sediment Production in Two Mediterranean Mountain Environments

J. Sevink

Soil Organic Horizons of Mediterranean Forest Soils in NE-Catalonia (Spain): Their

Characteristics and Significance for Hillslope Runoff, and Effects of Management and Fire

A.G. Brown

Soil Development and Geomorphic Processes in a Chaparral Watershed:

Rattlesnake Canyon, S. California, USA

T.P. Burt

Seasonality of Subsurface Flow and Nitrate Leaching

K. Rögner

Measurements of Cavernous Weathering at Machtesh Hagadol (Negev, Israel)

A Semiquantitative Study

M. Mietton

Mesures Continués des Températures dans le Socle Granitique en Region Soudanienne

(Fèvrier 1982-Juin 1983, Ouagadougou, Burkina Faso)

N. La Roca Cervigón \& A. Calvo-Cases

Slope Evolution by Mass Movements and Surface Wash (Valls d'Alcoi, Alicante, Spain)

A. Calvo-Cases \& N. La Roca Cervigón

Slope Form and Soil Erosion on Calcareous Slopes (Serra Grossa, Valencia)

J. Poesen \& D. Torri

The Effect of Cup Size on Splash Detachment and Transport Measurements

Part I: Field Measurements

D. Torri \& J. Poesen

The Effect of Cup Size on Splash Detachment and Transport Measurements

Part II: Theoretical Approach

A.C. Imeson \& J.M. Verstraten

Rills on Badland Slopes: A Physico-Chemically Controlled Phenomenon

L.A. Lewis

Measurement and Assessment of Soil Loss in Rwanda

C. Zanchi

Soil Loss and Seasonal Variation of Erodibility in Two Soils with Different Texture in the Mugello Valley in Central Italy

L. Góczán \& A. Kertész

Some Results of Soil Erosion Monitoring at a Large-Scale Farming Experimental Station in Hungary

H. Lavee

Geomorphic Factors in Locating Sites for Toxic Waste Disposal 


\title{
A METHOD FOR THE SEPARATION OF TOTAL DISCHARGE INTO BASE FLOW, OVERLAND FLOW AND CHANNEL PRECIPITATION FOR WATER QUALITY MODELLING OF A SMALL WATERSHED IN THE NETHERLANDS
}

\author{
W. Bleuten, Utrecht
}

\section{Summary}

For surface water quality modelling all contributing discharges, each with different loads of dissolved matter have to be considered separately. Apart from physical and (bio)chemical interactions, water quality is the result of all inputs, both in volume and mass. For this reason dynamic modelling of water quality is possible only when the processes leading to the temporal variability for each different type of input can be modelled as well.

In the Netherlands almost all inland watersheds discharge considerable amounts of groundwater. During storm events however, surface runoff is an important factor even in these flat areas. Other discharge sources to be modelled are channel precipitation and effluent discharges.

A dynamic one-dimensional numeric discharge model has been developed for

ISSN 0933-3630

(C) 1988 by CATENA VERLAG, D-3302 Cremlingen-Destedt, W. Germany $0933-3630 / 88 / 5011851 /$ US $\$ 2.00+0.25$ a catchment area in the central part of the Netherlands, with distinct subareas where infiltration or seepage is dominant. Model output is dayly discharge of the three most important discharge components (groundwater discharge, overland flow and channel precipitation) and total catchment outflow.

From these components groundwater discharge has been calculated using recorded levels of groundwater and surface water. Because precipitation volumes per day can be computed from meteorological data and surface water area, and effluent discharges usually are well known, overland flow discharge modelling was possible.

\section{Introduction}

The modelling of the quality of surface water requires detailed and quantitative information on discharge variability, both in time and space. Surface waters contain certain amounts of dissolved matter, originating from various sources. During transport these ions interact with (suspended) solid materials in the water, 


\begin{tabular}{|c|c|c|c|c|c|c|c|c|c|c|c|c|}
\hline & \multicolumn{2}{|c|}{$\mathrm{K}^{+}$} & \multicolumn{2}{|c|}{$\mathrm{Na}^{+}$} & \multicolumn{2}{|c|}{$\mathrm{Cl}$} & \multicolumn{2}{|c|}{$\mathrm{HCO}_{3}$} & mean & $\mathrm{NO}_{3}$ & \multicolumn{2}{|c|}{$\mathrm{PO}_{4}^{3}$} \\
\hline PD & 10.2 & $(4.4)$ & 14.5 & (4.6) & 24.7 & $(11.1)$ & 115. & (41.) & 18.7 & $(13.1)$ & 2.7 & $(1.7)$ \\
\hline $\mathrm{BF}$ & 4.3 & $(2.1)$ & 22.4 & (17.6) & 40.1 & $(30.5)$ & 184. & (37.) & 5.1 & $(6.1)$ & 2.0 & (1.4) \\
\hline $\mathrm{OF}$ & 4.7 & (3.1) & 14.9 & (6.5) & 24.7 & $(8.8)$ & 148. & (120.) & 40.5 & (41.3) & 2.7 & (3.4) \\
\hline $\mathrm{E}$ & 18.4 & (7.1) & 71.3 & $(36.0)$ & 79.6 & $(54.0)$ & 84. & (41.) & 63.2 & $(36.3)$ & 34.8 & (17.3) \\
\hline $\mathrm{P}^{*}$ & 0.1 & & 1.7 & & 3.1 & & 0. & & 3.8 & & 0.0 & \\
\hline
\end{tabular}

$\mathrm{PD}=$ peak discharge

$\mathrm{BF}=$ base flow (mainly groundwater discharge)

$\mathrm{OF}=$ overland flow

$\mathrm{E}=$ effluent water from purification plants

$\mathrm{P}=$ precipitation

* data from KNMI-RIVM, 1979

Tab. 1: Means of measured ion concentrations in surface water during peak discharge and base flow conditions and in overland flow water $\left(\mathrm{g} \cdot \mathrm{m}^{-3}\right)$.

the soil below the water and with living organisms. In modelling of water quality these interactions should be taken into account. Furthermore, each discharge component has its own quality properties, reflecting the environmental conditions in its source area. Therefore the various discharge components have to be separated in a quantitative way in order to facilitate real time modelling. In this context base flow (BF) resulting from groundwater discharge only, has physical and chemical properties quite different from precipitation, overland flow (OF) or effluents. Mean concentrations of six ions in surface water in the study area (see below) for BF conditions for OF and for the mixed surface water during peak discharge (PD) conditions, demonstrate clear, ion dependent, differences (tab.1).

Overland flow water compared to precipitation water has higher concentrations (SÜSSMAN 1983) because the first is enriched with soluble ions (in manure and fertilizer) from the top soil. Manure and fertilizer remnants on top of the soil can deliver these ions because of the common agricultural practice (over- dosing, manure spreading in winter).

Peak discharge concentrations seem to be the result of mixing of the three discharge components. For sodium, chloride and bicarbonate $\mathrm{PD}$ concentrations are dominated by inputs of $\mathrm{OF}$ and channel precipitation $(\mathrm{P})$. In this area both $O F$ and $P$ have lower concentrations then groundwater. For nitrate and to a lesser extent also for phosphate PD concentrations are increased because of OF inputs.

From a comparison between percentile values the differences between BF conditions and PD appear to be significant for some ions (fig.1). In these comparisons percentiles of the sorted field data are used because in surface waters ion concentrations are not normal distributed in time.

In particular nitrate and potassium concentrations are increased during PD priods (storms), probably resulting from the combination of $\mathrm{OF}$ and reworking of bottom sediments. The potassium increase can only be explained by the second cause as both OF and $P$ concentrations are lower than PD concentrations. 


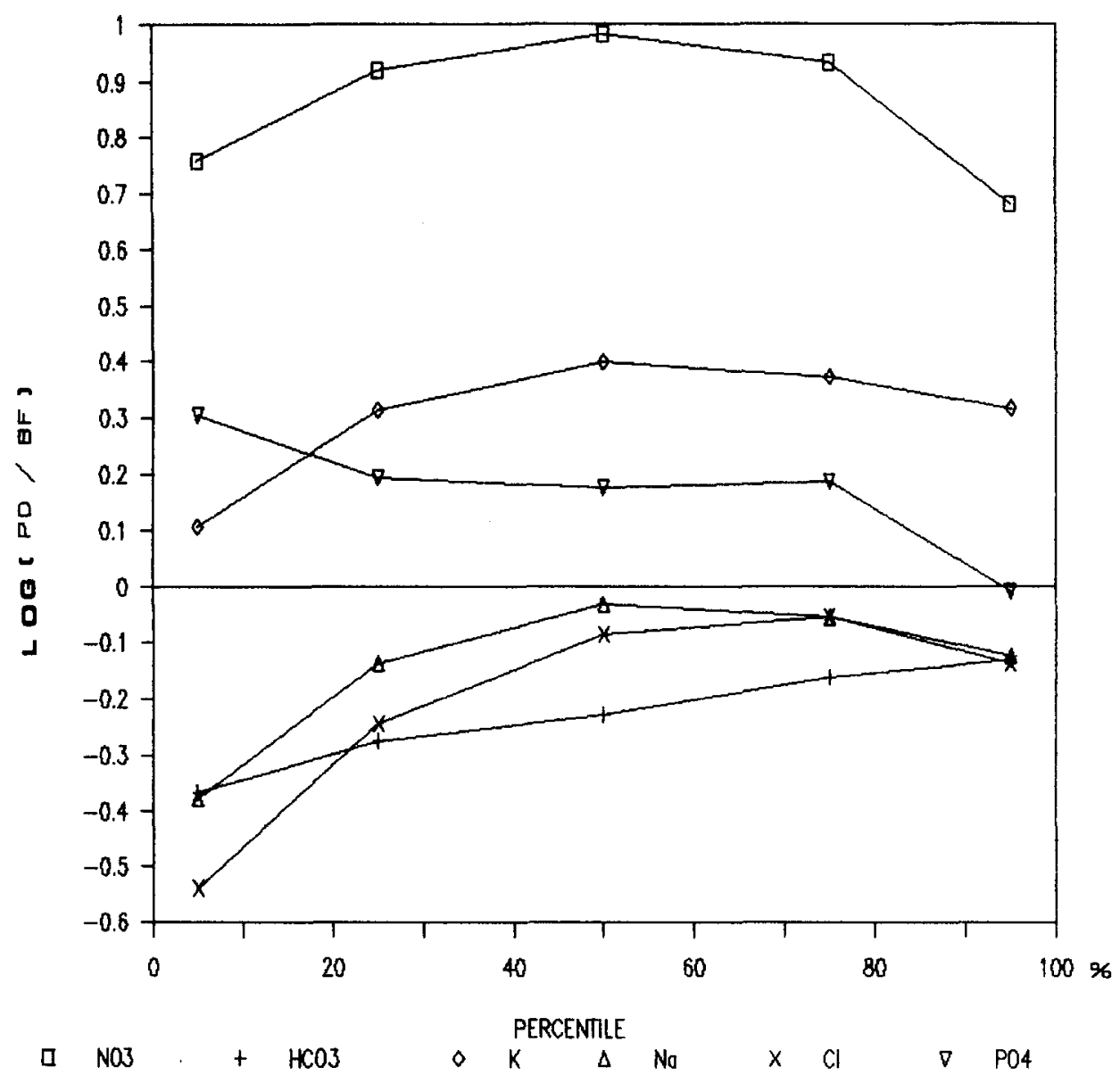

Fig. 1: Quotient of measured concentration percentiles during base flow (BF) and peak flow (PD) conditions.

The results point to the need to split total runoff into the various discharge components when modelling water quality. Channel precipitation discharge (QP) can be calculated from water surface areas (estimated or measured). Effluents from point sources usually are well known and quantified. Overland flow will be the component most difficult to measure in a representative way for whole catchments. However, if base flow is quantified, overland flow can be com- puted.

\section{Study area}

The catchment studied $\left(16 \mathrm{~km}^{2}\right)$ is situated in the centre of the Netherlands (Southeast of the town of Utrecht). Geomorphologically the area can be split up into three main parts (fig.2).

The Northeastern part consists of a morainic ridge ('Utrechts Heuvelrug') composed of ice pushed Pleistocene 
same magnitude. Thus, base flow conditions occur when:

$Q_{t+1}<Q_{t}<1.02 * Q_{t+1}$

$$
\begin{array}{ll}
\text { where } & \\
Q & =\text { discharge } \\
t & =\text { current day } \\
t+1 & =\text { next day }
\end{array}
$$

In the study area this condition (3) is satisfied within 3-5 days after a storm event with peak discharge. This means that after 5 days the total discharge consists of seepage. For computing the relation between water level differences (H) and groundwater discharge, only those measurements done 6 days after rain storms were selected. As expected from equations ( 1 and 2 ) the groundwater discharge appeared to be correlated strongly $(\mathrm{r}=0.9 ; \mathrm{p} \leq 0.001)$ with water level differences $(\mathrm{H})$ by a first order function (fig.3). Up to a level difference $(\mathrm{H})$ of $0.6 \mathrm{~m}$ the groundwater discharge can be predicted very well. At (almost) bankfull discharges the linear discharge-tolevel difference relation no longer holds true, so the function loses its validity. Because in the studa area bankfull discharge occurs only once every 2-3 years and the canals never dry out, the regression function can be used for continuous computation of groundwater discharge. The first order equation has been incorporated in a discharge model of the study area.

\subsection{Discharge due to channel precipitation}

The discharge resulting from channel precipitation is computed from the measured total water surface area and channel banks are above the water level. Both areas are dependent to water level chang- charge depletion curves constructed following weir elevation changes were used to calculate initial area sizes. These calculations were checked by map analyses and field work.

\subsection{Overland flow discharge}

Overland flow discharge has been modelled based on infiltration capacity and surface storage potential. In the flat study area overland flow occurs only on clay soils used for agricultural production. Infiltration capacity of clay soils depends strongly on their moisture conditions (BOUMA 1977). Therefore 'wet' and 'dry' infiltration capacities have to be differentiated in modelling overland flow. In places where surface storage occurs the soil is completely saturated with water, resulting in a very low ('wet') infiltration capacity (WIC). By shrinking of the clay during dry periods deep cracks are formed, resulting in very high 'dry' infiltration capacity (BOUMA 1977), or more accurate: the soil storage capacity increases. For modelling purposes an actual infiltration capacity (AIC) is computed with a simple function based on precipitation history (fig.4). This function is derived from the antecedent precipitation index equation of CHOW (1964). The discharge resulting from overland flow can be computed on a daily basis from precipitation and evaporation data after model calibration with a separate data set from a well recorded and documented peak discharge period. With the same data set the parameter values (IC, WIC, R) for the study area are set by means of iterations. 


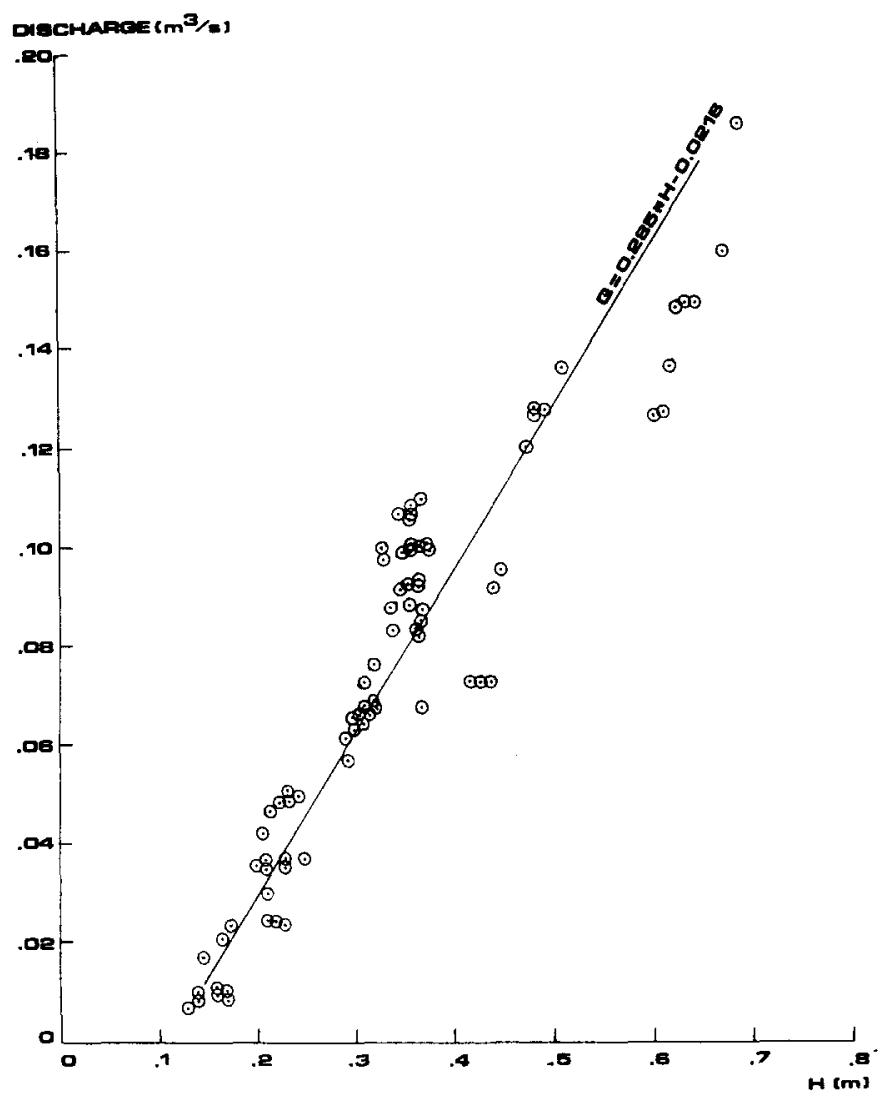

Fig. 3: Relation between groundwater discharge in dry periods and the difference $(H)$ between groundwater level and surface water level.

\begin{tabular}{||l|c|c||}
\hline discharge components & $\begin{array}{c}\text { sand area } \\
\text { type II }\end{array}$ & $\begin{array}{c}\text { clay area } \\
\text { type III }\end{array}$ \\
\hline total $\left(10^{6} \cdot \mathrm{m}^{3} \cdot \mathrm{y}^{-1}\right)$ & 1.2 & 4.8 \\
groundwater discharge \% & 97. & 68. \\
overland flow discharge \% &.- & 29. \\
channel precipitation \% & 3. & 3. \\
\hline
\end{tabular}

Tab. 2: Total annual discharge and precentage of contribution of separate discharge components for two parts of the study area. 


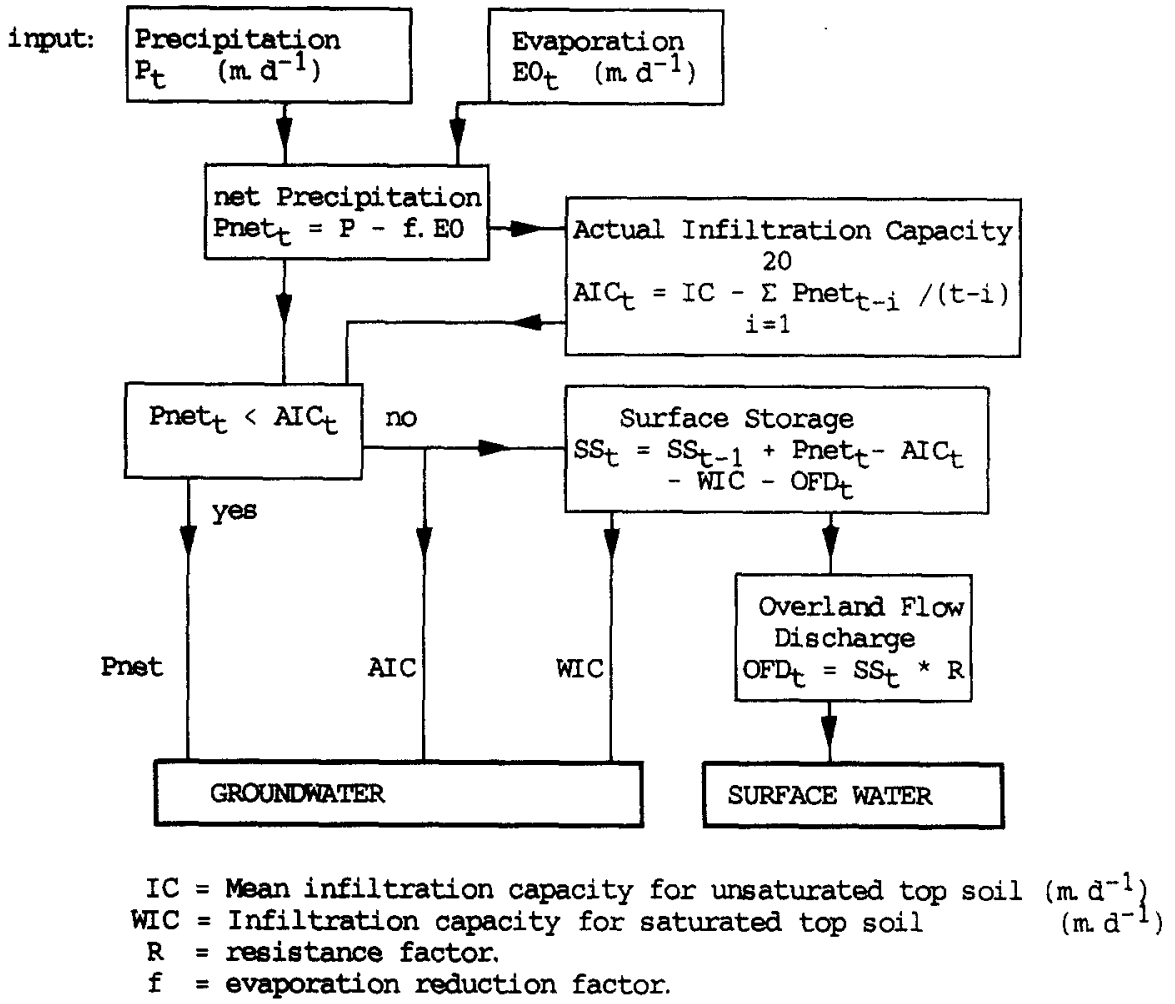

Fig. 4: Flow scheme for computation of overland flow discharge.

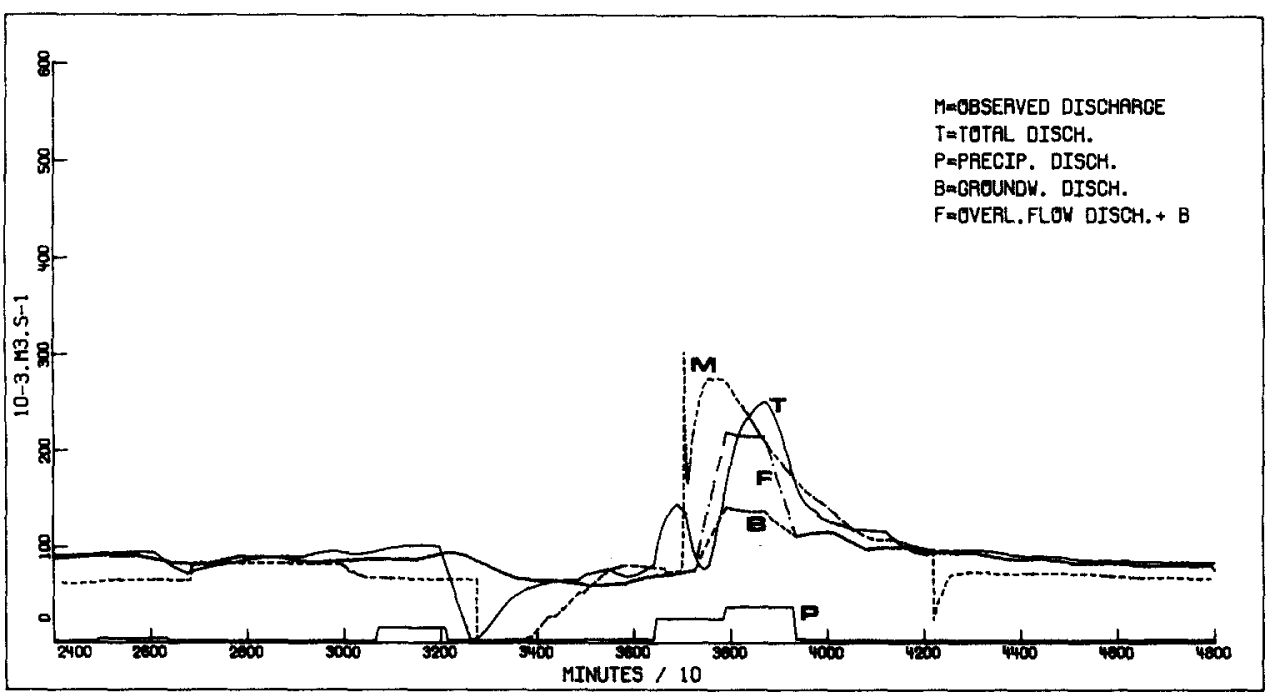

Fig. 5: Computed and observed discharge components. 


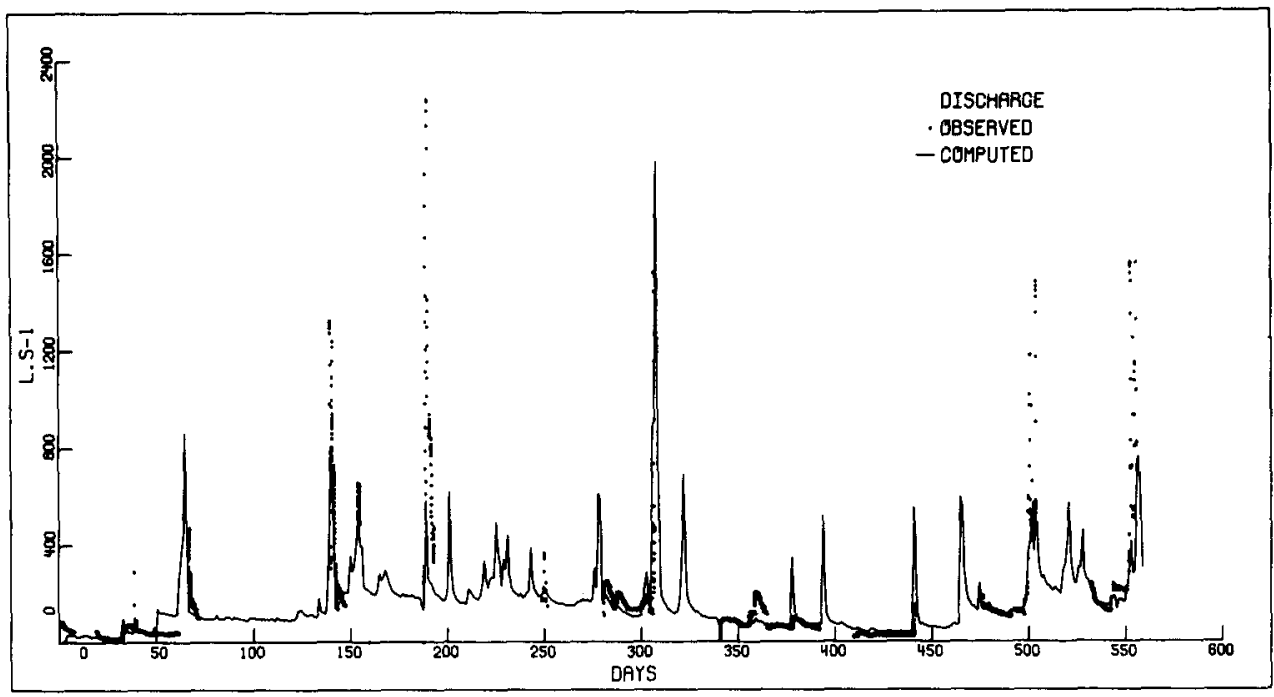

Fig. 6: Computed and observed total discharge from October 1978 - February 1980.

\section{Results}

The sum of the three discharge components forms the input of the discharge model of the study area. Discharge at the outlet of the catchment is computed from:

$Q=Q_{B F}+Q_{O F}+Q_{P}-S / t$

where

$S=$ Storage volume

Channel storage is computed from the difference between input volume and outflow capacity (volume), which in turn depends on the computed water level (wh) in the actual time step. For discharge computation, after testing for the study area the empirical formula (5) according ANN (1967) has been used.

$Q=c_{w} * B *(w h-w c h)^{3 / 2}\left(m^{3} \cdot s^{-1}\right)$

\footnotetext{
where

$c_{w} \quad=$ weir dependent constant

$B \quad=$ weir width $(\mathrm{m})$

wh = water level $(\mathrm{m})$

wch $=$ weir crest height $(\mathrm{m})$
}

This means that for computations the weir crest height should be well known from field observations.

Although part of the input data consist of daily figures the chosen time step is one hour, to obtain convergence in the calculations. In fig. 5 the results of the computations for period June-August, 1981 are plotted together with the observed total discharge. Except for precipitation the plotted curves give the moving averages of 5 hour blocks. The model structure brings on a one day delay compared to reality. In the observed hydrograph sudden changes occur. These result from farmers interfering with weir elevations.

In tab. 2 the discharge components for a whole year are added. On a yearly base overland flow in the clay soil area appears to contribute up to almost $30 \%$ of the total discharge, a quantity which cannot be ignored.

In fig. 6 computed and observed discharges at the outlet of the catchment 
are shown for the period October 1978

- February 1980. Base flow discharge is computed very accurately. Computed peak discharge does not always fit. This may result from underestimation of overland flow. The lack of field data regarding weir elevation changes can lead to miscalulations in both 'observed' and 'computed' discharges. This makes a goodness of fit test less meaningfull. After logarithmisation, thus depressing the importance of peak discharges, the correlation between 'observed' and 'computed' discharges was reasonable $\left(r^{2}=0.73\right)$. For modelling water quality, which is the ultimate purpose of this discharge model this correlation is acceptable.

\section{References}

ANN. (1967): Water measurement manual. U.S. Dept. of the Intern. Bur. of Recl.

ANN. (1974): Groundwater Map of the Netherlands 1:50000 (in Durch). Inst. for Applied Technology (TNO) - Department for Groundwater Survey.

ANN. (1979): Monitor network precipitation chemistry in the Netherlands (in Dutch). Royal Netherlands Meteorological Institute (KNMI), De Bilt, Volume 1979.

BERENDSEN, H.J.A. (1982): the geomorphogenesis of the south eastern part of the Province of Utrecht (in Dutch). Theses, Urechtse Geografische Studies, No. 25.

BLEUTEN, W. (1984): Some landscape ecosystem concepts based on spatial ground water movements. Ekologia (CSSR), Vol. 3, No. 1, 75-89.

BOUMA, J. (1977): Soil survey and the study of water in unsaturated soil. Soil Survey Papers (Soil survey Institute, Wageningen), No. 13.

CHOW, V.T. (Ed.) (1964): Handbook of applied Hydrology. McGraw Hill, New York.

HOOGHART, J.C. (Ed.) (1986): Terminology in hydrology (in Dutch, with synonyms in English). Comm. for Hydrological Res., TNO, Den Haag, Rapporten en Notas No. 16.

SÜSSMAN, W. (1983): Comparison of water quality in drainage basins under agricultural and forest land use. IAHS, Publ. No. 141, 431-441.
Address of author: Wladimir Bleuten

State University of Utrecht Institute of Geographical Research Department of Physical Geography Department of Environmental Sciences P.O. Box 80.115 NL - 3508 TC Utrecht The Netherlands 